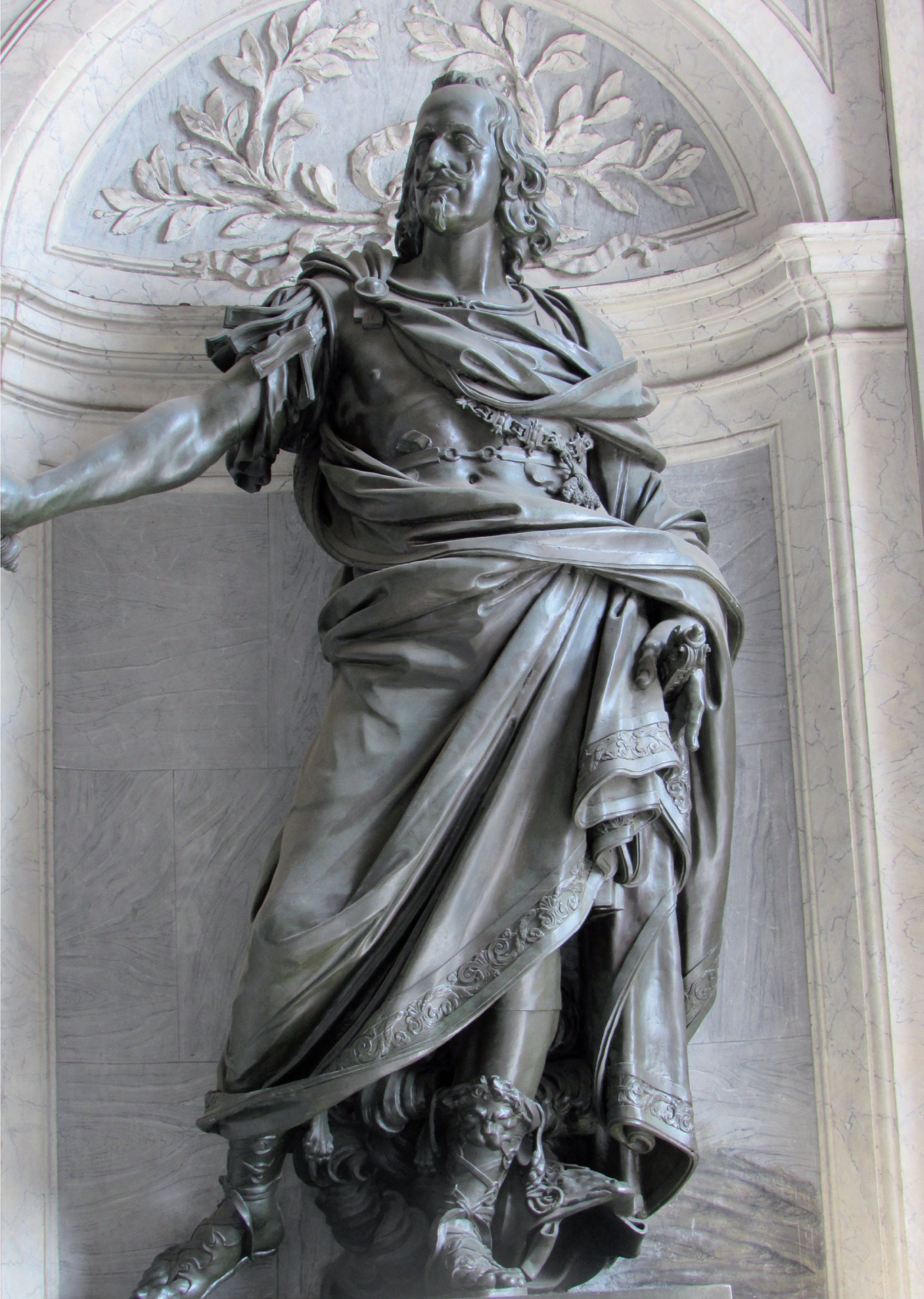




\title{
Festejando a una infanta: el bautizo de María Eugenia en Madrid, 1626
}

\author{
Celebrating an Infanta: Feast and Ceremony at the Baptism of Infanta María \\ Eugenia in Madrid, 1626
}

\author{
Sara Jarana Vidal \\ Université Bourgogne Franche-Comté, Besançon, France \\ sarajaranavidal@gmail.com \\ https://orcid.org/0000-0001-6738-932X
}

Recepción: 30/06/2020 | Aceptación: 02/10/2020

\begin{abstract}
Resumen
En 1625 nació la infanta María Eugenia, la tercera de las hijas del matrimonio compuesto por el rey Felipe IV y la reina Isabel de Borbón. Esta niña, nacida en veinte y uno de noviembre, fue bautizada en junio de 1626, con la pompa festiva propia de una infanta primogénita, ya que sus dos hermanas mayores habían fallecido al poco tiempo de nacer. Gracias a la relación de sucesos de Antonio Ferrari, de ese mismo año, podemos conocer muchos de los detalles que protagonizaron el día del bautismo de la pequeña infanta, incluido que sus padrinos fueron la reina de Hungría, doña María y el legado papal, el cardenal Barberini. En este trabajo analizaremos los datos existentes sobre el bautismo de la infanta, e intentaremos examinar los diferentes elementos del protocolo, propios de este tipo ceremonias.
\end{abstract}

Palabras clave

Infanta María Eugenia

Felipe IV

Isabel de Borbón

Relación de sucesos

Bautizo

Ceremonial

\author{
Keywords \\ Infanta María Eugenia \\ Felipe IV \\ Isabel de Borbón \\ List of events \\ Christening \\ Ceremony
}


No solo aquel que supera la infancia es digno de trascender a la Historia.

\section{Introducción}

Es habitual encontrar trabajos que tratan sobre las festividades y pompas reales en la Corte', y aunque es menos común hallar estudios sobre festividades por nacimientos y bautizos reales, existen algunas obras que analizan este tipo de ceremonias en el caso de príncipes herederos. Pero ¿qué ocurrió con aquellos niños que murieron al poco tiempo de nacer?, ¿no se realizaron festejos por su nacimiento, o bien, al no trascender a la historia, no han provocado interés alguno para la historiografía? Cuando un infante nace no se sabe cuánto tiempo va a vivir, si va a crecer hasta convertirse en rey o reina, o, por otro lado, si va a fallecer a los pocos meses, e incluso semanas de haber nacido. Por tanto, los festejos por el nacimiento y bautismo del hijo de un rey han de ser igualmente pomposos. Por supuesto, dependiendo del objeto de estudio, deberemos fijar nuestra atención en unos casos o en otros. El presente trabajo, que se encuentra inserto en uno de mayor envergadura, como es la tesis doctoral que venimos desarroIlando, trata de analizar el corpus ceremonial y la etiqueta durante el reinado de Felipe IV (Fig. 1). De este modo, nuestro interés radica en conocer en profundidad cómo se llevaron a cabo todas las ceremonias de su reinado, incluyendo las pompas regias por los miembros de la familia que trascendieron a la historia, y aquellos que han quedado relegados en el olvido, como la mayoría de los infantes nacidos de los dos matrimonios del monarca español.

El objetivo principal de este artículo es conocer con mayor profundidad cómo fue y de qué manera se desarrolló el bautizo de la infanta María Eugenia. Teniendo en cuenta el interés de Felipe IV por el ceremonial cortesano y por "asegurar el mantenimiento del orden

1. Debido a la naturaleza de este estudio se nos plantea imposible ahondar en toda la bibliografía existente en torno a las fiestas reales, ya que es una temática que ha suscitado mucho interés en la historiografía tanto española como europea; pero sí que mencionaremos a continuación algunos trabajos que nos han sido de utilidad en la elaboración de este texto: Ángeles Hijano Pérez, "Protocolo y ritual en los bautizos de la Monarquía Española," Libros de la Corte, no. 6 (primavera-verano 2013): 8-26; Fernando Bouza Álvarez, "El rey, a escena. Mirada y lectura de la fiesta en la génesis del efímero moderno," Espacio, Tiempo y Forma, Serie IV, Historia Moderna, no. 10 (1997): 33-52; Jesús Bravo Lozano, "La Capilla Real de Felipe IV: ceremonial de exaltación en un espacio integrador," Libros de la Corte, no. 11 (otoño-invierno 2015): 28-50; José Jaime García Bernal, El fasto público en la España de los Austrias (Sevilla: Secretariado de Publicaciones Universidad de Sevilla, 2006)(en esta obra podemos encontrar un capitulo dedicado a las celebraciones por natalicios: 251-261); José Jaime García Bernal, "De 'Felipe el Grande' al 'Rey Pacífico'. Discursos festivos y funerales durante el reinado de Felipe IV," Obradoiro de Historia Moderna, no. 20 (2011); 73-104; Juan Chiva Beltrán, "Triunfos de la Casa de Austria: entradas reales en la Corte de Madrid," Potestas. Estudios del Mundo Clásico e Historia del Arte 4, no. 4 (2011): 211-228; María Albadalejo Martínez, "Fasto y etiqueta de la casa de Austria. Breves apuntes sobre su origen y evolución," Imafronte, no. 19-20 (2008): 9-19; Pablo Vázquez Gestal, "La corte en la historiografía modernista española. Estado de la cuestión y bibliografía," Cuadernos de Historia Moderna, Anejos, no. 2 (2003): 269-310. 
a través de la insistencia en las preferencias y el seguimiento de un ritual social fijo e invariable" ${ }^{\prime 2}$, resulta de un gran interés comprender cómo se desarrollaron las fiestas y ceremonias por el nacimiento de una de las primeras hijas del monarca. Una infanta que nació a los pocos años de que su padre accediera al trono, y cuando las Etiquetas del soberano aún no estaban elaboradas. El presente estudio se ha elaborado teniendo en cuenta dos factores fundamentales: la peculiaridad de la fuente y la protagonista. Por una parte, usaremos como base para nuestro trabajo un género específico como es el caso de las relaciones de sucesos (aunque por supuesto, complementaremos la información

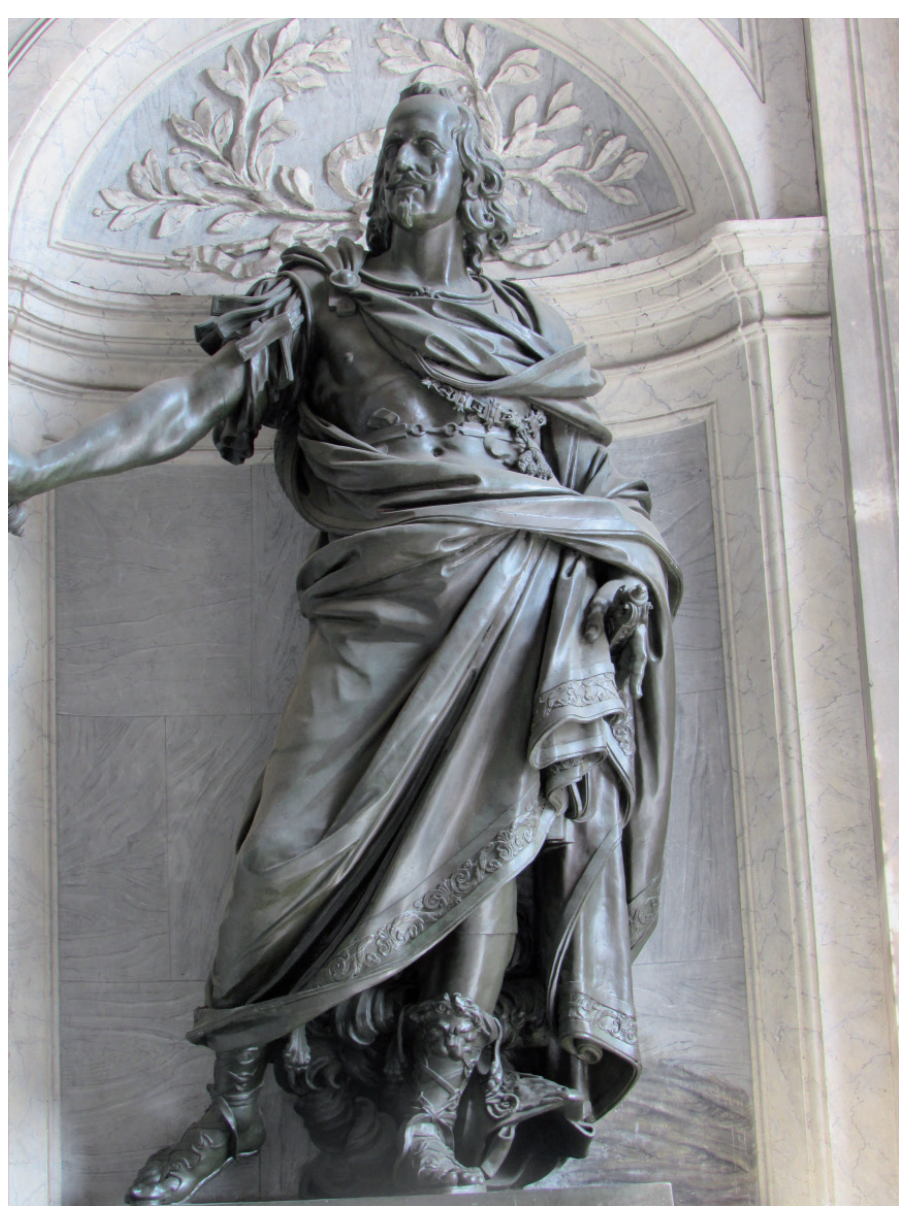

Fig. 1. Girolamo Lucenti y Gian Lorenzo Bernini, escultura de Felipe IV. Basilica di Santa Maria Maggiore, Roma. (Fotografía de la autora). que aporta con otros documentos, provenientes, entre otros, de expedientes del Archivo General de Palacio). Por otro lado, la intención de este estudio es la de acercarnos a la figura de la infanta María Eugenia, quien, a pesar de ser durante meses la primogénita y heredera del monarca, no ha sido objeto de estudio de la historiografía; sobre el nacimiento y bautismo de esta infanta apenas hemos podido hallar referencias bibliográficas, exceptuando principalmente los casos de Rodríguez Moya y De Carlos Varona, cuyos trabajos mencionaremos a lo largo de estas páginas.

Cabe destacar que de los hijos nacidos en el matrimonio de Felipe IV y su primera esposa, Isabel de Borbón, solo dos Ilegaron a edad adulta, la infanta María Teresa, que se convertiría en reina de Francia, y el príncipe Baltasar Carlos, que, a pesar de vivir toda su infancia, murió con apenas 17 años. El resto de los hijos murieron siendo prácticamente unos recién nacidos. Asimismo, de la descendencia del monarca, conocemos bien la trayectoria vital de varios de sus vástagos: el príncipe Baltasar Carlos, la infanta María Teresa (reina de Francia), la infanta Margarita, y por supuesto, Carlos II; del príncipe Felipe Próspero (1657-1661), quién no llegó siquiera a cumplir los 4 años contamos

2. Charles C. Noel, "La etiqueta borgoñona en la corte de España," Manuscrits, no. 22 (2004): 141. 


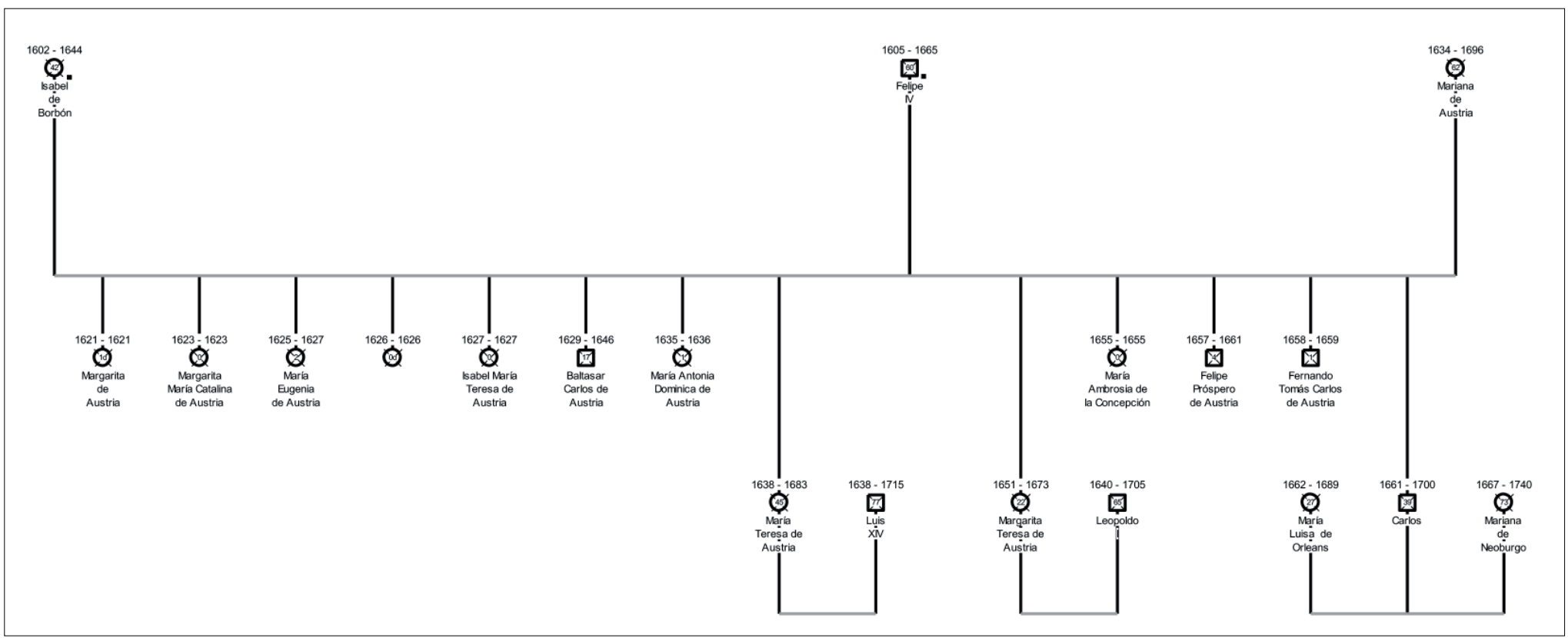

Fig. 2. Árbol genealógico de Felipe IV. (Elaboración propia).

con diversos trabajos bibliográficos que narran, fundamentalmente, las pompas reales que se llevaron a cabo por su nacimiento, ya que la llegada de un hijo varón tras más de 10 años sin un heredero masculino, suscitó el interés de toda la monarquía hispánica 3 . $Y$, en efecto, numerosas son las relaciones de sucesos que podemos encontrar sobre las celebraciones Ilevadas a cabo para festejar dicho acontecimiento. Incluso, contamos con un retrato del pequeño príncipe realizado por Diego Velázquez en el año 1659, cuando tendría en torno a los 2 años ${ }^{4}$.

Basta con que realicemos una búsqueda de la genealogía de Felipe IV en cualquier libro o enciclopedia, para darnos cuenta de que tan solo tres son los hijos que constan en cualquiera de ellas (María Teresa, Margarita y Carlos); o cinco en algunos casos, si cuentan a los príncipes Baltasar Carlos y Felipe Próspero. Es por este motivo por lo que hemos realizado un árbol genealógico del monarca en el que hemos incorporado a todos sus descendientes nacidos de sus dos matrimonios, sin excluir a aquellos que gozaron poco tiempo de vida (Fig. 2).

Si observamos con detalle el árbol genealógico y las fechas de nacimiento y defunción ${ }^{5}$ de las cuatro primeras infantas nacidas, podemos ver cómo ninguna de ellas llegó a vivir

3. Véase Hijano Pérez, "Protocolo y ritual," $10-11$.

4. Diego Velázquez, El príncipe Felipe Próspero, 1659. Óleo sobre lienzo, 128,5 ×99,5 cm. Gemäldegalerie. Kunsthistorisches Museum Wien.

5. La memoria de las llaves de los ataúdes de estos infantes, hasta el príncipe Baltasar Carlos, lo encontramos en Fallecimientos y entierros: memoria de las llaves de ataúdes de personas reales enterradas en el Monasterio de San Lorenzo de El Escorial desde Carlos I hasta el Príncipe Felipe Próspero, fecha sin determinar, Sección Histórica (SH), caja 56, expediente 6, Archivo General de Palacio (AGP), Madrid. 
el nacimiento de la siguiente hermana, por tanto, en su breve periodo de vida, cada una de ellas fue, en efecto, la única descendiente de Felipe IV y, por tanto, las primogénitas del rey. La primera de las hijas fue la infanta María Margarita que nació el 14 de agosto de 1621, al parecer, de forma prematura y murió a las 29 horas, el 15 de agosto de 16216. Tras ella, fue alumbrada en 1623, el día 25 de noviembre, la infanta Margarita María Catalina ${ }^{7}$, que fallecería poco tiempo después, el 22 de diciembre de ese mismo año ${ }^{8}$. Tras Catalina, la infanta María Eugenia nacería el día 21 de noviembre de 1625' y fallecería el 21 de julio de 1627, con tan solo 20 meses $^{10}$. Poco tiempo después de su fallecimiento, el 30 de octubre de ese mismo año de 1627, nacería la infanta Isabel María Teresa, que moriría horas después de llegar al mundo"1.

Tras las cuatro primeras infantas, en 1629 vino al mundo el que sería príncipe de Asturias durante 17 años, el príncipe Baltasar Carlos, heredero hasta 1646 $6^{12}$. Una vez que falleciera el príncipe, tan solo quedaría con vida la infanta María Teresa, nacida en 163813, quien garantizaría la sucesión de Felipe IV, ya que la hermana nacida entre Baltasar Carlos y María Teresa, María Antonia Dominica (en 1635), moriría igualmente a los meses de nacer ${ }^{14}$.

Tras la defunción de su esposa Isabel de Borbón en 1644, y sin tener heredero varón, Felipe IV volvió a casarse con su sobrina Mariana de Austria en 1649. De este matrimonio, como podemos ver en el árbol genealógico, la primera de los descendientes

6. Enrique Florez, Memoria de las reinas católicas (Madrid: Oficina de la Viuda de Marín, 1790), 2: 938.

7. Carta de Felipe IV al duque de Béjar dónde le informa del nacimiento de la infanta Margarita María Catalina, 29 de noviembre de 1623, caja 3620, documento 16, Archivo Histórico de la Nobleza (AHNo), Osuna.

8. Florez, Memoria de las reinas, 2: 940.

9. Expediente referente al nacimiento de la infanta María Eugenia, 21 de noviembre de 1625, Cédulas y Pragmáticas (CP), caja 10, expediente 3, Archivo de la Real Chancillería de Valladolid (ARCV), Valladolid.

10. Ángel González Palencia, Noticias de Madrid, 1621-1627(Madrid: Ayuntamiento de Madrid, Publicaciones de la Sección de Cultura e Información, 1942), 163: "a 21, a las nueve de la mañana, murió la Señora Infanta Doña María Eugenia, de veinte meses, hiciéronse muchas rogativas y procesiones por su salud; llevaron a San Lorenzo el Real su cuerpo".

11. González Palencia, 167: "a 30, parió la Reina nuestra Señora una hija que vivió veinte y cuatro horas; y la llevaron al Escorial".

12. Expediente por el que se da cuenta al Acuerdo del nacimiento del Príncipe Baltasar Carlos, 17 de octubre, 1629, CP, caja 10, expediente 20, ARCV, Valladolid; y expediente relativo a la muerte del príncipe Baltasar Carlos para que se pusiesen lutos en la Chancillería, 1646, CP, caja 11, expediente 45, ARCV, Valladolid. Sobre las festividades por el bautizo de Baltasar Carlos, véase: García Bernal, El fasto público, 254.

13. Expediente de la Infanta María Teresa, Reina de Francia, 1638, SH, caja 94, expediente 186, AGP, Madrid. Nació la infanta en 20 de septiembre.

14. Florez, Memoria de las reinas, 2: 946. La infanta nació en 17 de enero de 1635, y fue bautizada pocos días después, el 23 de enero de ese mismo año: De la Infanta María Antonia Dominica, 1635, SH, caja 94, expediente 185, AGP, Madrid. Erróneamente, en Carlos Robles do Campo, "Los infantes de España en los siglos XVI y XVII," Anales Real Academia Matritense de Heráldica y Genealogía, no. 9 (2005-2006): 410: el autor sitúa el nacimiento de la infanta en 17 de enero de 1636, algo que no puede ser así, ya que existe el citado expediente de nacimiento y bautizo de la infanta en el AGP, con fecha de 1635; de manera que se torna imposible bautizar a una infanta en 1635, que según este autor no nacería hasta enero de 1636. El fallecimiento de la infanta se produjo el 5 de diciembre de 1636, por lo que la niña no llegó a cumplir los dos años: Florez, Memoria de las reinas, 2: 947. 
nacidos sería la infanta Margarita, en 1651ํㅜ tras ella, una nueva infanta nacería para morir al poco tiempo, María Ambrosia de la Concepción (1655) $)^{16}$. Y, por fin, en 1657 nacería un nuevo heredero varón, el príncipe Felipe Próspero ${ }^{17}$. Tras Felipe y antes del fallecimiento de este, en 1658, volvería a nacer otro hijo del matrimonio que apenas viviría unos meses, el infante Fernando Tomás Carlos ${ }^{18}$. En 1661, tras la muerte de Felipe Próspero la Corona volvió a encontrarse durante unos días sin heredero varón, ya que el destino quiso que el día 1 de noviembre de 1661 falleciese el príncipe Felipe, para que tan solo 5 días después, el 6 de noviembre de ese mismo año, naciera el nuevo príncipe, y ahora sí, futuro rey Carlos $\|^{19}$.

Por todo lo ya citado, en el siguiente trabajo hemos seleccionado a una de las descendientes de Felipe IV e Isabel de Borbón, la infanta María Eugenia (1625-1627), para procurar analizar con detalle cómo fueron las celebraciones del nacimiento y bautismo de una infanta que, si bien falleció a los veinte meses de nacer, durante el periodo de vida que tuvo fue la única descendiente viva del rey, y sobre la cual apenas podemos encontrar ensayos ${ }^{20}$. Analizaremos a partir de una determinada documentación ${ }^{21}$, la celebración de bautismo de la infanta e intentaremos que, con este trabajo, podamos aportar algo más de luz historiográfica a la vida de esta infanta que, por el devenir de la historia, ha quedado prácticamente en el olvido y, sin embargo, podría haber llegado a ser reina. No obstante, debemos señalar que la selección del bautizo de María Eugenia

15. Margarita María nació el 12 de julio de 1651: Florez, Memoria de las reinas, 2: 954, y fue bautizada el 25 del mismo mes, tras la resolución del rey de que las insignias reales las portaran tres mayordomos suyos, y tres de la reina "los más antiguos", De la Infanta Margarita María, 1651, SH, caja 94, expediente 187, AGP, Madrid.

16. Florez, Memoria de las reinas, 2: 956. La infanta nació el día de san Ambrosio, el 7 de diciembre, recibió agua bautismal, y murió sin llegar a los quince días. Su cuerpo, al igual que el de los demás infantes, se llevó a El Escorial.

17. Del Príncipe Felipe Próspero, 1629, SH, caja 94, expediente 189, AGP, Madrid: El príncipe nació el día 28 de noviembre de 1657, y fue bautizado en jueves trece de diciembre de ese mismo año. Aunque el príncipe no llegaría a cumplir los tres años, falleciendo el 1 de noviembre de 1661, Florez, Memoria de las reinas, 2: 957.

18. Florez, Memoria de las reinas, 2: 956. "Parió la Reyna felizmente otro Infante en el año siguiente 1658, a 21 e diciembre, día del Apóstol santo Thomás, por lo que fue llamado D. Fernando Thomás" y "acabó de vivir en 23 de octubre de 1659, y yace en el Escorial con los demás".

19. Carta misiva de Felipe IV comunicando al conde-duque de Benavente el nacimiento de su hijo el príncipe Carlos José, futuro rey Carlos II, 1661, caja 434, documento 3, AHNo, Osuna; y del Príncipe Carlos (II), 1661, SH, caja 94, expediente 190, AGP, Madrid: hallamos también el expediente de bautismo, celebrado el veinte y uno de noviembre de ese mismo año.

20. María Cruz de Carlos Varona, Nacer en Palacio. El ritual del nacimiento en la corte de los Austrias (Madrid: Centro de Estudios Europa Hispánica, 2018), 58, 81, 86, 87, 91, 96, 98, 98, 102, 103, 105, 106, 107, 109, 128, 129, 197, 198 y 234. En este ensayo, la autora hace bastantes referencias a la infanta protagonista de este estudio, inclusive, a partir de su nacimiento (1625) desarrolla el capítulo titulado "El espacio del parto regio". Inmaculada Rodríguez Moya, "El bautismo regio en la corte hispánica: arte y ritual del siglo XVI al XVII," Archivo Español de Arte 91, no. 364 (octubre-diciembre 2018): 349-366; la autora hace un estudio de los bautizos en la Corte de los Austrias, y en el cuál podemos encontrar referencia a la infanta María Eugenia, de la que vamos a hablar: 358, 359, 360 y 363, e incluye una tabla con los detalles de bautismo de 10 de los hijos nacidos de Felipe IV: 358.

21. Trabajaremos principalmente a partir de relaciones de sucesos, ya que consideramos, resulta una fuente muy interesante para este estudio y, a su vez, complementaremos la información de estas relaciones con algunos expedientes del AGP. 
sobre los demás existentes, en concreto sobre el de la infanta María Catalina, se debe a la peculiaridad de su caso, en el que el periodo transcurrido entre el nacimiento y la celebración de su bautizo fue de seis meses, lo que supone un hecho insólito para la época. La espera del cardenal Barberini resultaría de especial interés para la monarquía hispánica, quien tendría en alto aprecio el hecho de que el mismísimo papa, representado en la figura del cardenal, fuese el padrino de la recién nacida infanta.

Como ya hemos comentado, la infanta María Eugenia, nacida en 21 de noviembre de 1625 y fallecida el 21 de julio de $1627^{22}$ fue la tercera de las hijas nacidas del matrimonio real, tras dos años del nacimiento y fallecimiento de su hermana la infanta Margarita María Catalina, y tras cuatro del de su hermana Margarita ${ }^{23}$. Si bien, en el presente estudio vamos a enfocar nuestra atención en esta infanta, muchos son, como ya hemos referido, aquellos nacimientos y defunciones reales pendientes de estudio y que, en esta ocasión y de manera coyuntural, iremos tratando en el trazado de este trabajo. De Ios descendientes del rey que no llegaron a edad adulta, Felipe Próspero, es quien más interés ha suscitado por su condición de heredero de la Corona, pero, la segunda hija de Felipe IV, Margarita María Catalina fue la primera descendiente en ser bautizada con pompas reales. De esta manera, el bautizo de Margarita María Catalina supuso el primer bautizo real del recién estrenado rey Felipe IV. La celebración de este bautismo asentaría las bases del corpus de este tipo de ceremonias durante su reinado, aunque esto no significará que todos los bautizos se realizaran de la misma forma ni en el mismo lugar. Es por este motivo que el expediente de bautismo de la infanta Margarita María Catalina es, sin duda alguna, el más extenso de entre todos los de sus hermanos ${ }^{24}$.

\section{Las fuentes}

La historiografía no se ha ocupado en gran medida del estudio de los bautizos, vida y defunción de estas infantas, por lo que deberán ser las fuentes originales de la época quienes nos ayuden a desarrollar este artículo, de manera que el género de las relaciones de sucesos se torna fundamental, siendo la principal fuente de estudio para unos acontecimientos que apenas han suscitado interés posteriormente; o, en otras palabras, si tenemos en cuenta la falta de documentación sobre ellas elaborada con el paso

22. Véanse cita 6 y 7.

23. Véanse cita 3 y 4.

24. Nacimientos y bautizos Felipe IV: de la Infanta Margarita María Catalina, 1623, caja 94, expediente 182, AGP, Madrid. 
de la historia, hemos de ir a su presente, cuándo sí fueron reconocidas como las figuras que fueron, infantas de España, para poder conocer un poco más sobre ellas.

Si consultamos la obra de Alenda y Mira ${ }^{25}$, cinco son las notas referentes al bautismo y celebración por el nacimiento de la infanta María Eugenia; ocho las referentes al nacimiento de Margarita María Catalina, y ninguna en referencia a la infanta María Teresa, sobre la que no hallamos nota al respecto.

\begin{tabular}{|c|c|c|c|}
\hline Título o intitulación de la relación & $\begin{array}{l}\text { Lugar de } \\
\text { publicación }\end{array}$ & $\begin{array}{l}\text { Año de } \\
\text { publicación }\end{array}$ & Impresor / Autor \\
\hline $\begin{array}{l}\text { Relación de las fiestas, torneos, y saraos de Bar- } \\
\text { celona al nacimiento de la Infanta nuestra señora }\end{array}$ & Barcelona & 1625 & $\begin{array}{l}\text { Por Sebastián de } \\
\text { Cormellas }\end{array}$ \\
\hline $\begin{array}{l}\text { Aparato festivo en el bautismo de la serenissima } \\
\text { Infanta D. Maria Eugenia, celebrado con esplén- } \\
\text { dida pompa en la Real Capilla de su Magestad, a } \\
\text { siete de junio deste presente año de } 1626\end{array}$ & Madrid & 1626 & $\begin{array}{l}\text { Por Antonio Ferrari, en } \\
\text { casa de Bernardino de } \\
\text { Guzmán }{ }^{26}\end{array}$ \\
\hline $\begin{array}{l}\text { Aparato festivo en el bautismo de la serenissima } \\
\text { Infanta D. Maria Eugenia, celebrado con esplén- } \\
\text { dida pompa en la Real Capilla de su Magestad, a } \\
\text { siete de junio deste presente año de } 1626\end{array}$ & ¿Madrid? & ¿1626? & $\begin{array}{l}\text { "Plagio declarada de la } \\
\text { anterior" }\end{array}$ \\
\hline $\begin{array}{l}\text { Relación manuscrita sobre el bautizo de la Infanta } \\
\text { doña Maria Eugenia, celebrado el } 7 \text { de junio de } 1626\end{array}$ & Madrid & 1626 & $\begin{array}{l}\text { Relación manuscrita de } \\
\text { Gerónimo Gascon de } \\
\text { Torquemada. }\end{array}$ \\
\hline
\end{tabular}

Relación de bautismo de la Señora Infante Doña

Madrid

Maria Eugenia [hija de Felipe IV] de quien fue pa-

drino el Cardenal Don Francisco Barberino, legado

a Latere por su santidad, el Papa Urbano VIII, en 7

de junio de 1626

Tabla 1. Resumen de las relaciones de sucesos sobre el bautizo de la infanta María Eugenia en la obra de Alenda y Mira ${ }^{27}$. (Elaboración propia).

25. Jenaro Alenda y Mira, Solemnidades y fiestas públicas de España (Madrid: Establecimiento Tipográfico "Sucesores de Rivadeneyra", Impresores de la Real Casa, 1903), 214-256.

26. Aunque en la obra de Alenda no aparece reflejado el nombre del autor, hemos podido constatar que se trata de Antonio Ferrari, y de cuyo ejemplar existen varias ediciones.

27. Alenda y Mira, Solemnidades y fiestas, 247, 250-256. 


\begin{tabular}{|c|c|c|c|}
\hline Título o intitulación de la relación & $\begin{array}{l}\text { Lugar de } \\
\text { publicación }\end{array}$ & $\begin{array}{c}\text { Año de } \\
\text { publicación }\end{array}$ & Impresor \\
\hline $\begin{array}{l}\text { Bautismo de la Serenísima Infanta Doña María } \\
\text { Eugenia, en la Real Capilla de su Magestad, a siete } \\
\text { de junio de } 1626\end{array}$ & & & $\begin{array}{l}\text { Manuscrita }{ }^{28} \\
\text { (Fig. 3) }\end{array}$ \\
\hline $\begin{array}{l}\text { Aparato festivo en el bautismo de la serenissima } \\
\text { Infanta Doña Maria Eugenia, celebrada con es- } \\
\text { plendida pompa en la Real Capilla de su Magestad, } \\
\text { a siete de lunio deste presente año de } 1626\end{array}$ & Sevilla & 1626 & Juan de Cabrera ${ }^{29}$ \\
\hline $\begin{array}{l}\text { Aparato festiuo en el bautismo de la Serenissima } \\
\text { Infanta D. Maria Eugenia: celebrado con esplendi- } \\
\text { da pompa en la Real Capilla de Su Majestad a Siete } \\
\text { de lunio deste presente año de } 1626\end{array}$ & Madrid & 1626 & $\begin{array}{l}\text { Por Antonio Ferrari en } \\
\text { Casa de Bernardino de } \\
\text { Guzmán }{ }^{30}\end{array}$ \\
\hline $\begin{array}{l}\text { Aparato festivo, en el bautismo de la serenissi- } \\
\text { ma infanta doña Maria Eugenia, celebrado con } \\
\text { esplendida pompa en la real capilla de su ma- } \\
\text { gestad, a siete de junio deste presente año } 1626 \text {. } \\
\text { Y el parabien que dieron los embaxadores del } \\
\text { emperador a sus magestades del casamiento de } \\
\text { la serenissima infanta con el rey de Ungria hijo de } \\
\text { la cesarea magestad }\end{array}$ & Barcelona & 1626 & $\begin{array}{l}\text { En Casa de Sebastián y } \\
\text { Jaime Matevad }{ }^{31}\end{array}$ \\
\hline
\end{tabular}

Tabla 2. Ediciones de la obra de Antonio Ferrari32. (Elaboración propia).

Prestando atención a las relaciones de la tabla presentada anteriormente, para el presente estudio, usaremos la relación de Antonio Ferrari, impresa por Bernardino de Guzmán. Pero antes de continuar y proceder a su análisis conviene que distingamos las distintas versiones que hemos encontrado del mismo pliego, y cuyo autor es igualmente Ferrari. Además de estas, merece la pena subrayar que existe otra relación que bien podría ser otra copia de la relación narrada por Ferrari, y que se encuentra traducida al italiano, pero que no hemos podido corroborar por el momento ${ }^{33}$.

28. Ejemplar disponible en Bibliothèque Municipale Besançon, Fondo Jules Chifflet, Colección Pièces historiques cérémoniales, tomo I. No queda reflejado si es copia de manuscrito o impreso, y de mano de quién ha sido elaborada. Pero como hemos podido comprobar, se trata de una copia manuscrita de la composición original de Ferrari, aunque no sabemos si fue el propio Jules Chifflet, o alguien de su taller quien realizó de forma manuscrita esta copia.

29. Ejemplar disponible en el Fondo Antiguo de la Universidad de Sevilla (Biblioteca Rector Machado y Núñez). El autor de esta relación impresa es Antonio Ferrari, autor a su vez de la impresa en Madrid por Bernardino de Guzmán: Universal Short Title Catalogue, IN: 5038039.

30. Ejemplar disponible en la Real Academia Española, Biblioteca Nacional de España: MSS/2358(H.348R.-349V.), y Biblioteca Digital Hispánica.

31. Ejemplar disponible en la Biblioteca Central de la Universitat de Barcelona.

32. Las diferencias entre los ejemplares impresos recaen levemente en el formato, incluyendo la impresa por Bernardino de Guzmán, con una portada en la que dedica su trabajo al marqués de Rol.

33. Relatione dell'apparato festivo, fatto nel battesimo della serenissima Infanta donna Maria Eugenia. Celebrato con splendida pompa nella cappella reale di sua maestà alli 7 di giugno del presente anno 1626. Tradotta dallo spagnolo in italiano, Roma 1626. Por Lodovico Grignani, y 


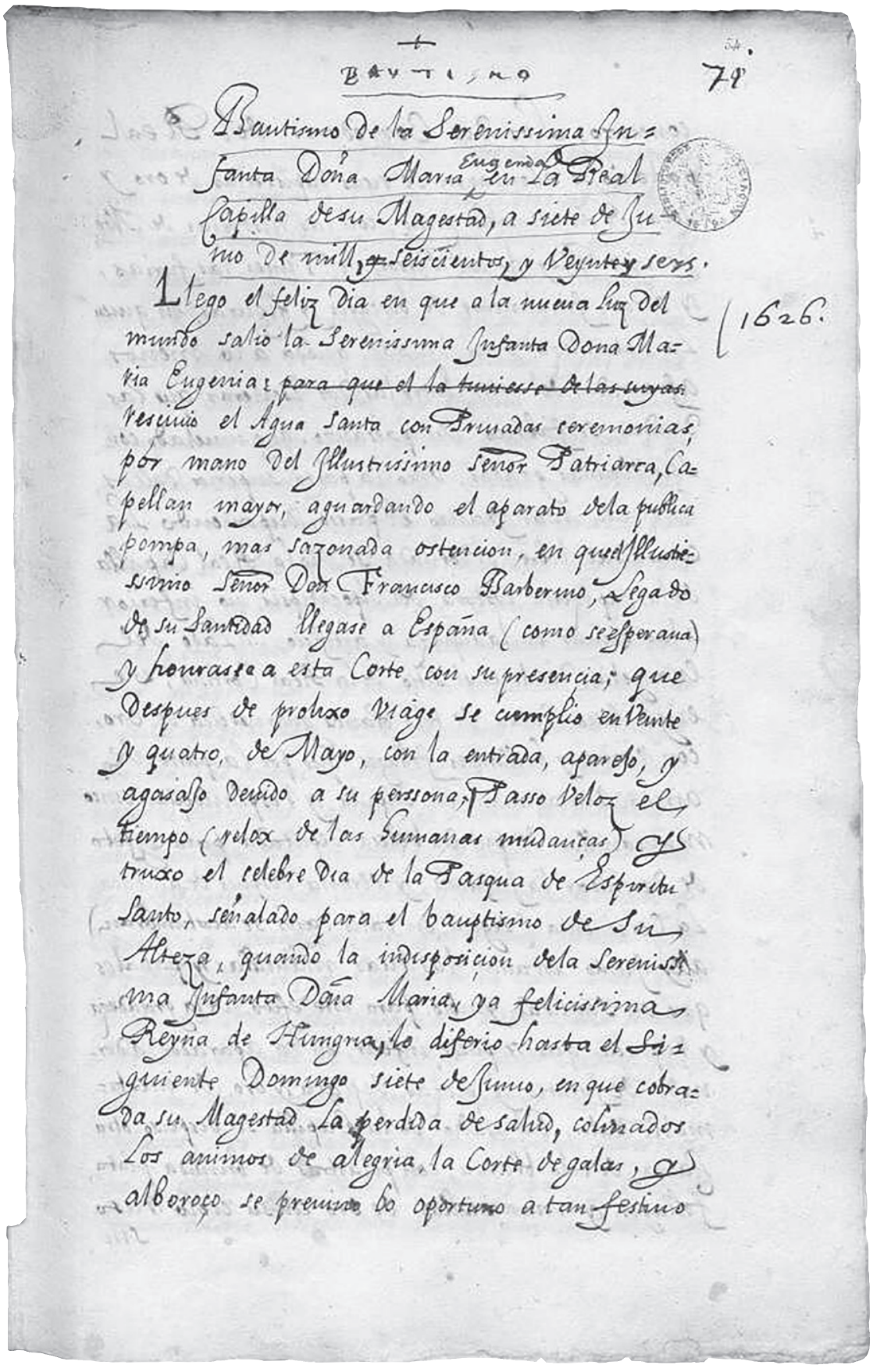

Fig. 3. Imagen primera página relación de sucesos de la colección Jules Chifflet. Bibliothèque Municipale Besançon, Fondo Jules Chifflet, Colección Pièces historiques cérémoniales, tomo I.

Como hemos mencionado, las diferentes ediciones de la relación de sucesos de las que nos vamos a ocupar a continuación, y que citamos en la tabla anterior, contienen exactamente la misma información, a excepción de la impresa en Madrid por Bernardino de Guzmán, la cual incluye una portada con dedicatoria. Resulta interesante que prestemos atención a esta ofrenda que hace Antonio Ferrari, puesto que este dedica su obra al "Marqués de Rol, Feudatario Imperial, Embaxador del Serenisimo Señor Duque de Módena,

vendido en Pasquino da Francesco Florino: ejemplar disponible en Biblioteca Nazionale Centrale de Roma. En la Biblioteca Nacional de Roma podemos encontrar ambos ejemplares, la traducción italiana y la original en castellano. 
Cavallero del Abito de Santiago"34. Ferrari, capellán de la Corona de Italia entre 1618-163135, era natural de Madrid, aunque su padre, Jacomé era oriundo de la ciudad de Módena; y, al mismo tiempo que desempeñaba su labor como capellán en la Corte de Madrid, también trabajaba para el duque de Módena, de quien era agente. Precisamente era en casa del embajador del duque, el marqués de Rol, dónde Ferrari se hospedaba ${ }^{36}$, por lo que no resulta extraño que fuera este marqués el que recibiera la dedicatoria de su obra.

\section{La celebración del bautizo}

A pesar de que la infanta María Eugenia nació en veintiuno de noviembre de 162537, la niña no fue bautizada hasta el siete de junio de 1626, un hecho que resulta bastante inaudito para la época, ya que, a la precaución habitual venida de la alta mortalidad infantil, habría que sumar la muerte prematura de sus dos hermanas mayores, por lo que lo normal era que se temiera por la vida de la criatura, que podría fallecer sin haber recibido el sacramento. Es por ello por lo que a pesar de que la infanta no recibiría el sacramento del bautismo completo hasta junio de 1626, a los pocos días de nacer, sí que se le echó el "agua de bautismo"38. De suma importancia debía ser la razón por la que se tardó tantos meses en bautizar a la niña en la iglesia con toda su ceremonia. Más aún si tenemos en cuenta que, como refiere Charles Noel, Felipe IV fue el monarca de su dinastía que más interés mostró en mantener la etiqueta cortesana "en todo su rigor", entendiendo la etiqueta "como un pilar del poder Habsburgo, y una fuente de orden y fortaleza moral"39. La razón de esta dilación pensamos que no fue otra más que esperar a la llegada del legado papal, el cardenal Francesco Barberini, quien, por razones diplomáticas, viajó por Francia entre

34. Ferrari, Aparato festivo en el bautismo (tabla 2).

35. José Martínez Millán y José Eloy Hortal Muñoz, dirs., La Corte de Felipe IV (1621-1665). Reconfiguración de la Monarquía católica (Madrid: Ediciones Polifemo, 2015), 2: 2184.

36. Martínez Millán y Hortal Muñoz, dirs., 2: 1214: "vivía en la casa de su embajador, circunstancia que le servía para no hacer frente a sus pagos y deudas, esquivando la justicia de la capilla".

37. Expediente referente al nacimiento de la infanta María Eugenia. El expediente se encuentra formado por una carta de su majestad, el rey Felipe IV, en la que informa al presidente de la Real Audiencia y Chancillería de Valladolid del nacimiento de la infanta, el cual se produjo "a veinte y uno del presente a las once horas de la mañana". Documento firmado por el propio rey a veinte y dos días de noviembre de 1625. Sobre la hora del nacimiento encontramos otra versión: De Carlos Varona, Nacer en Palacio, 86, dice que María de la Presentación (como la autora hace referencia en su libro a María Eugenia) nació pasadas las nueve y media de la mañana; quien a su vez refiere a la obra de Diego de Guzmán:, 9-476, 285r-286v, Real Academia de la Historia(RAH), Madrid. En cualquiera de los casos, queda claro que la niña nació en la mañana del veinte y uno de noviembre, antes de mediodía.

38. De Carlos Varona, Nacer en Palacio, 106-107. Cita la autora: "el 5 de diciembre de 1625 hubo que practicarle un 'cauterio debajo de la oreja por prevención de salud' echándole agua de bautismo, aunque sin imponerle crisma, que se dejó con las oraciones para cuando tuviera lugar la ceremonia en la iglesia", 107, en 9-476, fol.290v-290r, RAH, Madrid. para conocer más detalles de cómo aconteció el alumbramiento de la infanta María Eugenia, véase: De Carlos Varona, Nacer en Palacio, 86, 87, 96, 97, 98, 99, $102,105$.

39. Noel, "La etiqueta borgoñona," 144. 
mayo y octubre de 1625, y no llegó a Madrid hasta mayo de 1626. El cardenal, legado del pontífice, iba a ser el encargado de apadrinar en nombre del papa, a la infanta María Eugenia ${ }^{40}$; la espera de tan insigne padrino bien podría merecer la demora en la celebración de dicho evento.

Según la relación de Antonio Ferrari, el cardenal Barberini no entró en la Corte hasta el día veinte y cuatro de mayo "con la entrada, aparejo y agasajo debido al valor de su persona, si ajustado al decoro de su ministerio"41, pero según cuenta Enrique Florez, el cardenal visitaría a la reina ya el día 6 de mayo cuando dice:

El Papa la envió el parabién de su feliz parto por medio del Cardenal Barberino, que visitó à la Reyna en 6. de Mayo, teniendo silla enfrente de la de su Magestad en la misma tarima. La recién nacida Intanta estuvo en brazos de la Condesa de Olivares con silla à la izquierda de la Reyna: más la niña lo hizo tan bien, que no cesó de llorar mientras duró la visita, por más que la Condesa procurara acallarla meneando los diges y la campanilla ${ }^{42}$.

Lo cierto es que, el bautizo, preparado para celebrarse a fines del mes de mayo hubo nuevamente que posponerse por la indisposición de la que iba a ser la madrina, la infanta María, hermana de su majestad Felipe IV. Por todo ello, la celebración por el bautismo de la pequeña infanta no se celebraría hasta el día 7 de junio de 1626. Asimismo, entre el nacimiento y el bautizo de la infanta (noviembre de 1625, y junio de 1626) otra fecha hemos de destacar, el día uno de enero de 1626, cuando la reina doña Isabel de Borbón salió a la misa de parida; "la reina salió al Oratorio con la señora Ynfanta en brazos, y su vela encendida en las manos; acompañaban a Su Magestad la del Rey Nuestro Señor, el Señor Ynfante Carlos, los Señores Ynfantes Carlos y María"43. Desde el nacimiento de María Eugenia y hasta el día uno de enero la reina se encontró en el periodo denominado como "puerperio", que tal y como indica De Carlos Varona "era un periodo destinado a la recuperación física y psicológica de la madre durante el cual la compañía de las reinas era ante todo femenina", un periodo de en torno a cuarenta días que variaría en función de las condiciones físicas y psicológicas de la madre ${ }^{44}$.

40. Silvano Giordano y Salvador Salort Pons, "La legación de Francesco Barberini en España: unos retratos para el cardenal y un breve pontificio para Diego Velázquez, 'clericó coniugato'," Archivo Español de Arte, no. 77 (2004): 160.

41. Ferrari, Aparato festivo en el bautismo (tabla 2).

42. Florez, Memoria de las reinas, 2: 943

43. Nacimientos y bautizos Felipe IV: de la Infanta María Eugenia, 1625-1626, SH, caja 94, expediente 183, AGP, Madrid. En este último documento se hace alusión a la decoración que se usó en la misa de parida de la reina.

44. De Carlos Varona, Nacer en Palacio, 106. Sobre el cuidado de la reina tras el parto, véase: 106, 107, 108, 114, 115. 


\section{El escenario}

El bautizo de la infanta María Eugenia se celebró el siete de junio de 1626 en la Capilla Real del Alcázar de Madrid ${ }^{45}$. Para tal insigne ocasión, tanto el palacio como la capilla se adornaron muy ricamente. Ferrari dice que los dos corredores del Palacio Real se decoraron con ricas tapicerías de oro y seda ${ }^{46}$. Más concretamente se encontrarían vestidos con los tapices que narran La historia de Noé, La Historia de Ciro el Grande, la empresa de Túnez, y también otros citados como "boscajes y figuras"47, que, según Rodríguez Moya, podrían tratarse de Galería de Jardinez. Los tapices de Noé y La empresa de Túnez también se utilizaron para la celebración de otros de los hijos de Felipe IV, teniendo los primeros su origen en un encargo de Carlos $V$, aunque comprados por Felipe II; y los demás, siendo encargos de Felipe ${ }^{48}$.

La serie de Noé destaca porque, según indica Checa, en tres de los cuatro ejemplares de la serie (Dios ordena a Noé que construya el Arca, Noé construye el Arca, Noé sale del arca con su familia y los animales y Noé sale del arca con su familia y los animales) existen unas cenefas que no rompen completamente con la escena narrada en el paño, sino que, por el contrario, se integran visualmente en él ${ }^{49}$. No obstante, en la descripción de Patrimonio Nacional, se indica que este detalle se incluye en los cuatro paños de la serie:

La singularidad de los cuatro paños de la serie encargada por Felipe II, y que no presentan las otras historias de Noé, se encuentra en las aves y animales representados en sus cenefas, reflejo de las aficiones del rey por este tipo de representaciones naturalistas. Dichos animales son prácticamente idénticos a los que aparecen en este cartón, destacando la exquisitez y belleza con que están tratados, especialmente, los más exóticos ${ }^{50}$.

45. Nacimientos y bautizos Felipe IV: de la Infanta María Eugenia.

46. Etiquetas Generales de Palacio, 1650, Códices, libro 1496, 164, Archivo Histórico Nacional (AHN), Madrid. Queda indicado en las Etiquetas que tanto la iglesia como la capilla han de colgarse de tapicerías ricas. Para el estudio del ceremonial dispuesto en el bautizo de la infanta María Eugenia, resulta de especial interés el análisis de las tapicerías empleadas en tal ocasión. En el estudio más amplio que estamos desarrollando, correspondiente con nuestra tesis doctoral, esperamos poder ahondar más acerca de qué tapices fueron empleados en las distintas ceremonias y cuáles fueron los motivos que determinaron su elección; razones que, a nuestro entender, debieron estar ligadas a la posición sucesoria que ocupaba cada infante, así como al propio contexto político en el que se encontraba la monarquía hispánica cuando se produjeron los nacimientos de los sucesivos herederos.

47. Ferrari, Aparato festivo en el bautismo (tabla 2).

48. Rodríguez Moya, “El bautismo regio en la corte," 363.

49. Fernando Checa, Tesoros de la Corona de España. Tapices flamencos en el Siglo de Oro (Madrid: Fons Mercator, 2010), 238 (en esta misma referencia podemos hallar una reproducción del paño citado). Estos tapices de La historia de Noé se usaron también previamente en 1623, en el bautizo de la infanta María Catalina: Nacimientos y bautizos Felipe IV: de la Infanta Margarita María Catalina.

50. Patrimonio Nacional, "descripción de la obra Michiel Coxcie, El embarque en el arca de Noé," consultado el 25 de junio de 2020 , https:// www.patrimonionacional.es/colecciones-reales/pintura/el-embarque-en-el-arca-de-noe 
La serie de Ciro, por su parte, es la única serie de temática referida a la Antigüedad que ha llegado completa a nuestros tiempos, y que se compone de "diez paños de tapicería de oro, plata, seda y lana de la Historia de Ciro". Una obra cuyos cartones se atribuyen a Michel de Coxcie estaría basada en "Los nueve libros de Historia de Herodoto"51.

En cuanto a los paños de La empresa de Túnez, fueron, a priori, un regalo de Carlos V a su hijo Felipe con la intención de que los tapices fuesen mostrados en su ceremonia de matrimonio en Winchester ${ }^{52}$; y parece ser que este solo sería usado en la ceremonia de María Eugenia, no repitiéndose así en la ceremonia de sus hermanos ${ }^{53}$. La serie estaría compuesta por doce paños que narrarían los "hechos más importantes de la campaña tunecina del emperador [Carlos V] en 1535", y cuya realización corrió a cargo del taller de Willem de Pannemaker. A lo largo de las doce piezas "se narra la partida de las tropas imperiales, la llegada de la flota imperial a Túnez, la toma de La Goleta y la toma de Túnez, con profusión de detalles, siendo además un interesantísimo documento histórico para conocer el desarrollo de la campaña, y un catálogo de tipos humanos, pertrechos, armamento, paisajes, realmente singular ${ }^{\prime \prime 5}$.

Para rematar la decoración de los corredores, entre las dos escaleras que los dividían se fabricó un pasadizo "nivelado con las últimas gradas" que lo unía con la parte superior, de manera que haría "más franco el paso"55. El pasadizo habría de ser de madera entablado, e iría "desde la pieza donde espera el acompañamiento (...) que está sobre el zaguán", y debería ser aproximadamente de siete varas de alto, para que por debajo pudiera pasar cómodamente la gente de a pie, tal y como se indica en las Etiquetas Generales de Palacio elaboradas en tiempos de Felipe IV ${ }^{56}$. En el bautizo de la infanta María Catalina se indica precisamente que la altura del pasadizo fue de siete pies, mientras que de largo tenía setecientos y de ancho veintidós ${ }^{57}$.

51. Checa, Tesoros de la Corona, 225. Según este autor, los paños ya se encontrarían en la ciudad de Madrid a comienzos del reinado de Felipe II, siendo utilizados en ceremonias funerarias.

52. Checa, 215.

53. Rodríguez Moya, "El bautismo regio en la corte," 363.

54. Jesús F. Pascual Molina: "Los tapices de la empresa de Túnez," Arte, Poder y Sociedad en la Edad Moderna, consultado el 26 de junio de 2020, https://arteysociedad.blogs.uva.es/multimedia/exposiciones-virtuales/el-viaje-de-las-obras-de-arte/los-tapices-de-la-empresa-de-tunezl

55. Ferrari, Aparato festivo en el bautismo (tabla 2).

56. Etiquetas Generales de Palacio, 162. Las Etiquetas que citamos en el presente estudio, son una edición de 1650, por lo que algunos de los detalles que veremos en el modo de celebrar este bautismo, no quedan recogidos tal cual en las Etiquetas de 1650; pero también veremos cómo muchos de los elementos del bautizo de María Eugenia en 1626 se corresponderán con las indicaciones posteriormente registradas en las Etiquetas.

57. Nacimientos y bautizos Felipe IV: de la Infanta Margarita María Catalina. 


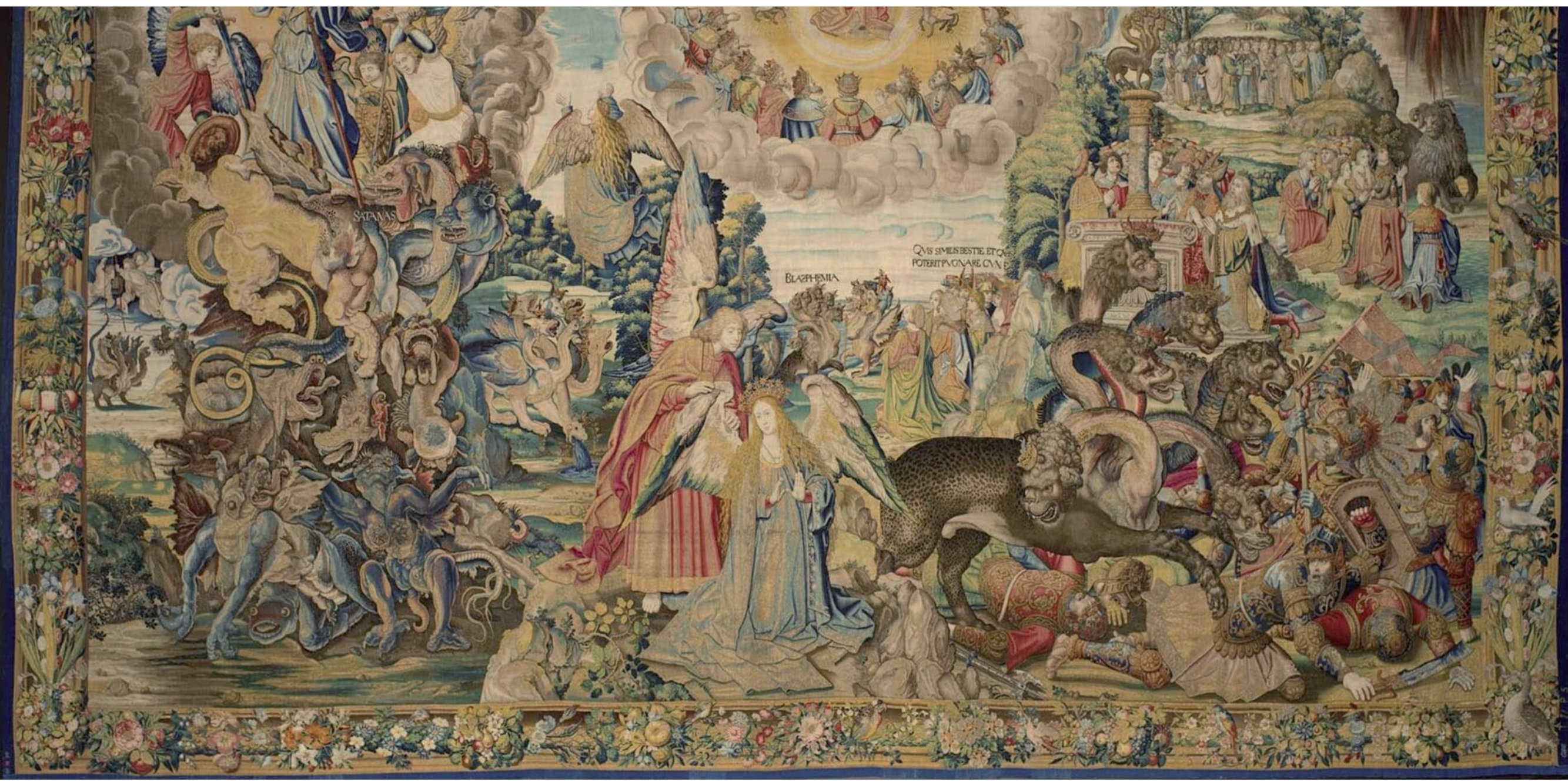

Fig. 4. Taller de Willem Dermoyen, San Miguel vence al demonio de la serie El Apocalipsis. Patrimonio Nacional. Museo de Tapices, Palacio Real de la Granja de San Ildefonso.

Ya en la Capilla Real, otra serie de tapices destacaría en su decoración: dice Ferrari, que este espacio se vio adornado con la costosa tapicería del Apocalipsis, la cual era"no inferior a las demás en la riqueza y artificio"58. El paño San Miguel vence al demonio(Fig. 4), de la serie de El Apocalipsis, hubo de ser uno de los expuestos en la Capilla Real el día siete de junio de $1626^{59}$. La serie El Apocalipsis fue encargada a mediados del siglo XVI por Felipe II; la primera parte de la serie se perdió casi en su totalidad en el mismo viaje de su envío desde Flandes, aunque tras el percance, el rey solicitaría de inmediato rehacer el conjunto, por lo que volvió a tejerse en Flandes. Los paños de la serie miden siempre más de cinco metros de altura y más de ocho de longitud, por lo que nos encontramos, como

58. Ferrari, Aparato festivo en el bautismo (tabla 2). El autor hace referencia a los tapices anteriormente citados, y que decorarían los corredores de palacio.

59. Esta serie también sería expuesta en el bautizo de María Teresa (1638) y Carlos II (1661), en Rodríguez Moya, "El bautismo regio en la corte," 362-363. 
cita Fernando Checa, "ante uno de los grandes encargos tapiceros de la casa Habsburgo española en el siglo XVI"60.

Además de los tapices, narra Antonio Ferrari que, al lado del Evangelio, en el lugar de la Real Cortina, se situaría una cama de tela blanca, guarnecida de oro "con varios y brillantes follages", y que estaría rematada por una cúpula. En ella resplandecían "cinco mançanillas de estremada belleza" y que estaría "dispuesta" para desnudar a la infanta y vestirla después de acabada la ceremonia, tal y como era costumbre. Allí se encontrarían en un aparador adornado de "pieças de plata y oro de inestimable valor", las ricas mantillas y pañales que su santidad envió como presente "de la grandeza y riqueza que se puede inferir"61. "En medio de la Capilla Mayor se hace una tarima de doce pies en cuadro, a la cual se sube por dos gradas, y en medio de ella se pone la pila"62. Asimismo, aquí se hallaría otra cama de tela blanca con pilastras de plata bruñida y manzanillas de oro con cielo de raso. Justo en el centro se encontraba la pila, que en este caso era la de santo Domingo, una reliquia de los reyes que "veneraban para semejantes ocasiones". La pila estaría adornada con plata de mucha costa y poseería un pedestal triangulado, e incluso, se encontraría cubierta de un tafetán carmesí "cuyas perlas pendían hasta el suelo". Y a propósito del suelo, este estaba cubierto de "finísimas alfombras turquescas", las cuales simulaban un ameno prado ${ }^{63}$.

\section{El acompañamiento e ilustres invitados}

"Salió el acompañamiento del quarto de la Reyna nuestra señora, y fue por los corredores a entrar a la capilla, yendo delante los alcaldes de la corte, y luego los entillers y jentiles hombres de la casa, a quién seguían los jentiles hombres de la boca"64; "Madrid usurpó este día las colores a Aranjuez, lo varió de los matizes a sus cultos jardines y

60. Checa, Tesoros de la Corona, 231.

61. Ferrari, Aparato festivo en el bautismo (tabla 2).

62. Etiquetas Generales de Palacio, 162.

63. Ferrari, Aparato festivo en el bautismo (tabla 2). Sin embargo, no se hace referencia en esta relación de que, al lado del Evangelio, se situaran cuatro fuentes y dos aguamaniles, como se indica en las Etiquetas Generales de Palacio que se ha de proceder. Por el contrario, la pila bautismal que se usa es en la que debió ser bautizado santo Domingo, que debía traerse del monasterio de su advocación, situado en Caleruega (en Castilla la Vieja): Etiquetas Generales de Palacio, 164. Cabe destacar que en la actualidad la pila bautismal de santo Domingo se encuentra en el monasterio de Santo Domingo el Real, en la ciudad de Madrid. Y, asimismo, se sigue usando en la actualidad por la Casa Real para bautizar a los miembros de la familia. Por añadidura, y para concluir con este apartado, debemos referirnos Rodríguez Moya, "El bautismo regio en la corte," 353-355, ya que en estas páginas la autora introduce varios documentos de la sección de planos del AGP donde podemos observar visualmente cómo sería la distribución de la iglesia que hemos ido narrando a través de fuentes documentales.

64. Nacimientos y bautizos Felipe IV: de la Infanta María Eugenia. 
venció a los Hebleos con tanta diversidad de costosas y luzidas libreas, ansi de los llustrisimos señores Cardenales, Legado y Zapata, y Cavalleros, sus familiares, como de Grandes, Títulos y Señores de la Corte"65. El acontecimiento merecía sin lugar a duda toda la pompa festiva de la monarquía; aunque recordemos que María Eugenia era la tercera de las hijas nacidas del matrimonio real, era la primera en sobrevivir más de unas semanas, hija primogénita al fin, y heredera de Felipe IV, que iba a ser bautizada por el legado del propio papa.

Según nos indican las Etiquetas Generales de Palacio, resuelto el día en que ha de celebrarse el bautismo, el rey envía orden al mayordomo mayor, el conde de Arcos en este caso, para que este previese todo lo necesario, así como para que distribuyera las diferentes tareas entre los distintos mayordomos de palacio. Debía, también, indicar a los grandes las insignias que debían llevar, y procurar el orden a la entrada de la iglesia por los desórdenes que se pudieran ocasionar ${ }^{66}$. Pues bien, todo previsto, tal y cómo se indicaba, a las "quatro de la tarde el Embaxador de la Magestad Cesárea, acompañado de algunos Cavalleros y familiares suyos, vestido de negro, y gala, con ricos botones, cadena y cintillo de diamantes, fue a besar la mano de la Reyna de Vngría, que con su Magestad en el quarto de la Reyna le aguardaba para este efeto". Una visita que se alargaría hasta las cinco y media de la tarde, cuando comenzaría el acompañamiento desde los aposentos de la reina Isabel ${ }^{67}$. Mientras tanto, el legado papal con sus prelados y su familia se vistieron pomposamente y aguardaron a que diera inicio la celebración. El cardenal Zapata iba a ser el encargado de oficiar el sacramento, y, por tanto, iba vestido de pontifical; a Zapata lo asistían el arzobispo de México y el obispo de Elves ${ }^{68}$. El acompañamiento hasta la Capilla Real procedió de la siguiente forma:

65. Ferrari, Aparato festivo en el bautismo (tabla 2).

66. Etiquetas Generales de Palacio, 163. Además de al mayordomo mayor, las Etiquetas señalan que el rey avisa también al caballerizo mayor, así como al mayordomo mayor de reina e infantes, al presidente de Castilla, para que avise a los consejos (Consejo de Indias, Ordenes, Hacienda, además de Aragón, Inquisición, Portugal, Italia y Flandes), y a los cardenales, a quienes ha de enviar mensaje con su secretario para que estén presente en el bautismo; además de, por supuesto, al capellán mayor.

67. Ferrari, Aparato festivo en el bautismo (tabla 2). La infanta María fue declarada esa misma tarde reina de Hungría, "por haberse publicado en el quarto de la Reyna el casamiento con el Rey de Hungría, hijo del Emperador", Florez, Memoria de las reinas, 2: 943. Según Ferrari, sus majestades, el rey Felipe IV y su esposa Isabel de Borbón, "la abraçaron amorosamente, y hizieron las devidas corteses ceremonias".

68. Relaciones de bautizos reales y de oficiantes, 1651-1799, SH, caja 94, expediente 188, AGP, Madrid. El cardenal Zapata fue el encargado de oficiar no solo el bautizo de María Eugenia, sino que también ofició los de la infanta María Margarita Catalina en 1623 y el del príncipe Baltasar Carlos en 1629. El siguiente bautizo real fue el de la infanta María Teresa, en 1638, fecha en la que el cardenal Zapata ya había fallecido, por lo que los encargados de oficiar la ceremonia de bautismo fueron el cardenal don Gaspar de Borja, y el arzobispo de Sevilla. 
Primeramente, iban los familiares del cardenal, "en tropa", seguidos de ellos, "los del príncipe Filiberto, con su acostumbrada gala y lucimiento"; tras ellos, doce pajes de su majestad con costosos trajes. Posteriormente, el cortejo seguía con los acroyes, gentiles hombres de boca, ayudas de cámara y de caballerizas (en gran número), yendo todos muy "muy bien aderezados". Acto seguido, los condes, títulos y otros particulares. Después seguía el crucero de su ilustrísima, y a este, los cuatro maceros reales, con sus mazas al hombro, y tras estos, cuatro reyes de armas con sus insignias; y para finalizar, iban ocho mayordomos con báculos, los cuales iban organizados de dos en dos; estos dos últimos, los reyes de armas y los mayordomos con báculos acompañaban al cortejo precisamente por tratarse de una infanta primogénita ${ }^{69}$.

Detrás de esta primera parte, venían los grandes, todos muy ricamente vestidos, y que eran: el duque de Sesa, duque de Maqueda, que portaba una fuente dorada con toaIlas para la infanta, seguidamente, el duque de Alburquerque, que llevaba otra bandeja, esta con el salero. El condestable de Castilla les seguía portando el mazapán con forma de corona imperial ${ }^{70}$. Tras el condestable venían el conde de Agamon con el aguamanil, don Duarte de Vergança con la vela y el duque del Infantado con el capillo. Y al fin, tras estos, el conde de Benavente con la infanta en los brazos ${ }^{71}$, a quien su majestad hizo "tan señalado favor"72.

La infanta iba vestida con un "baquerillo de tela de plata, con sombrerillo negro y blancas plumas, yba muy linda, obligando darla mil bendiciones a los que la miraban"73; aunque al parecer, la pequeña lloró y dio gritos ${ }^{74}$. Tras la pequeña infanta, un poco más atrás venía la madrina, la reina de Hungría, quien iba "vestida de noguerado, leonado y oro, con brillantes joyas y piedras, y saya entera muy vistosa"; la condesa de Lemos, su

69. Ferrari, Aparato festivo en el bautismo (tabla 2). Los maceros con sus mazas y los reyes de armas con sus insignias acompañaban a este cortejo por tratarse del bautizo de "Ynfanta Primogénita" o bien, "Príncipe heredero", ya que si no fuese así no deberían de ir acompañando al pequeño infante, tal y cómo queda indicado en las Etiquetas de palacio: Etiquetas Generales de Palacio, 168.

70. Rodríguez Moya, "El bautismo regio en la corte," 360: al parecer el mazapán, al igual que fue en el caso del de la infanta Margarita María Catalina, era de alfeñique (un tipo especial de pasta de azúcar).

71. Ferrari, Aparato festivo en el bautismo (tabla 2).

72. Etiquetas Generales de Palacio, 166. Dicen las Etiquetas que el infante a bautizar, "unas veces va en brazos de un Gran Señor, a quien su Magestad haze tan señalado favor (...) otras veces va en silla en los brazos de su Aya, y la llevan los reposteros de camas con unas vandas al cuello, y ayudan los Ayudas de Cámara para más seguridad". También se especifica aquí que, si quien porta a la infanta es persona real, ha de llevar traje, una ropa grande y tafetán al cuello, y si no lo es, va descubierto. En el bautizo de la infanta Margarita María Catalina, en 1623, el favor del rey recayó sobre el conde de Olivares, quién, no siendo persona real, y, cumpliendo con lo establecido en las Etiquetas, iba descubierto, con "ropa rozagante de brocado negro, calçones y ropilla bordados; llevaba una banda de tafetán carmesí guarnecida de oro al cuello", Nacimientos y bautizos Felipe IV: de la Infanta Margarita María Catalina.

73. Ferrari, Aparato festivo en el bautismo (tabla 2).

74. González Palencia, Noticias de Madrid, 1621-1627, 141-142. 
camarera mayor le llevaba la falda ${ }^{75}$, tal y cómo se especifica en las Etiquetas de palacio: "los padrinos, si son personas reales, les llevan la falda la camarera mayor"76. A la izquierda iría el ilustre padrino, el legado papal, y detrás de él, la condesa de Olivares, aya de la infanta, y que en esta ocasión iba de la mano del marqués de Liche, que iba "costosamente vestido de pardo con tomadillos sobre tela de oro". Seguidamente, eran el cardenal Nuncio y los embajadores de Alemania, Francia y Venecia quienes les seguían ${ }^{77}$. Y detrás de ellos, continuaban los prelados y camareros de su santidad, estos, vestidos de morado.

Posteriormente, las veinte y cuatro damas, que lucían adornos de colores, "joyas, cadenas, diamantes, gorrillas con plumas y tocados rozos" de manera que, según Ferrari, las damas "transformaron a junio en un vistoso abril". Las damas iban de dos en dos (al igual que los mayordomos anteriormente citados), y cada una de ellas iba acompañada de un caballero, al lado, y un menino atrás, que debían ocuparse de llevar la falda a las damas.

Y al fin, entrando el cortejo en la Capilla Real, los instrumentos tocaban para apaciguar el ambiente. En la capilla, según indica Antonio Ferrari, aguardaban: un capellán de honor con la cruz, así como dos pajes con hacha, el maestro de ceremonias y el receptor. El cardenal Zapata, junto a su séquito, se acercó a la cancela de la capilla, aguardando la llegada de sus majestades y hacer "humilde inclinación a sus Magestades y serenísimos Infantes -Carlos y Fernando estaban ya en la ceremonia- pero hubo de llegar la reina de Hungría, junto con el ilustrísimo legado papal y el conde de Benavente, quien recordemos, portaba a la infanta María Eugenia. De este modo, estando la niña ya en la capilla se procedió a dar comienzo a la ceremonia ${ }^{78}$.

\section{La celebración del sacramento}

Una vez se encontraba todo el acompañamiento en la capilla comenzó la ceremonia "en la ordinaria forma y hechas sus preguntas, pasaron a la pila, ministrando cada uno

\footnotetext{
75. Ferrari, Aparato festivo en el bautismo (tabla 2).

76. Etiquetas Generales de Palacio, 166.

77. El hecho de que los padrinos fueran por delante de los embajadores contradice lo que quedará estipulado posteriormente en las Etiquetas Generales de Palacio, que indica que han de ir primero los embajadores, y tras ellos el padrino y la madrina. Esto se ha de deber a que en 1626 aún se encuentran en un momento muy temprano de su edición; las cuáles no serán publicadas hasta mediados del siglo XVI, Etiquetas Generales de Palacio, 169.

78. Ferrari, Aparato festivo en el bautismo (tabla 2).
} 
lo que tenía a su cargo". Se procedió, de ese modo, a desnudar a la pequeña infanta: le quitaron el vaquero y la niña quedó en paños menores, así, la tomó el legado en sus brazos; junto a él, "y de una mano, la Reyna de Vngría; se prosiguió el acto poniéndola solo la Chrisma, por tener recibida, como está dicho, el agua del santo Bautismo", y le dieron por nombre María Eugenia. Acabado el sacramento, el cardenal Zapata, quién oficiaba la ceremonia, entonó el Te Deum laudamus, le siguieron los cantores. Para finalizar el rito eclesiástico, el cardenal dijo la oración y dio la bendición. Tras ello, el ilustre padrino, a través de dos capellanes que lo asistían concedió "quinientos años de indulgencias".

Tras la ceremonia, el cardenal se desprendió de los aparatos pontificales y a la infanta la vistieron nuevamente, para volver, en el mismo orden con el que llegaron a la capilla al cuarto de la reina. Y ya terminada la festividad eclesiástica, en palacio se sirvió merienda para las damas y se celebró comedia en el salón, a donde también asistieron los reyes Felipe e Isabel. En palacio se encendieron luminarias así como en otras casas de la ciudad. Cita Ferrari que, en particular, destacaron las del conde de Agamon, quien las "mandó a poner luzidísimas" en su casa, donde celebró una gran fiesta79. Y parece que la celebración se extendió en otros ámbitos, ya que el monarca Felipe IV obsequiaría al legado papal con doce mil ducados de rentas sobre los obispados de Sevilla, Málaga y Granada ${ }^{80}$.

\section{Conclusiones}

Como consideraciones finales, de lo expuesto en este estudio se desprende, por una parte, que la celebración por el nacimiento y bautizo de la infanta María Eugenia estuvo a la altura del de una infanta o príncipe heredero, con toda la pompa propia del ceremonial cortesano del reinado de Felipe IV. Esta se trató de una celebración en la que se siguieron, a grandes rasgos, los principios del corpus ceremonial que quedaría años después recogido en las Etiquetas Generales de Palacio de Felipe IV. No obstante, al tratarse de un bautizo celebrado a los pocos años de iniciarse el reinado de este monarca, el patrón festivo de la celebración no se correspondió en su totalidad con lo estipulado en las Etiquetas; el corpus de esta celebración, por lo tanto, aunque sentará las bases de los bautizos reales venideros, sufrirá modificaciones a lo largo de los años

79. Ferrari, Aparato festivo en el bautismo (tabla 2). 80. González Palencia, Noticias de Madrid, 1621-1627, 142. 
hasta quedar fijado por la junta de la Etiqueta. La elección como padrino de la infanta María Eugenia del cardenal Barberini representa un hecho singular de este caso concreto de bautismo, ya que determinó el momento en el que se produjo la celebración, así como la forma y los detalles con los que esta se llevó a cabo.

Tenemos que señalar como parte del corpus ceremonial de los bautismos reales de los herederos de Felipe IV varios elementos comunes fundamentales, entre ellos, que el cardenal Zapata sería el encargado de oficiar el bautismo de los infantes hasta el año 1629; y, los tapices de la Historia de Noé serán utilizados en reiteradas ocasiones para decorar el escenario de las ceremonias de bautismo, lo que denotaría la preferencia del monarca por estos tapices.

Por otro lado, queda de manifiesto la necesidad de indagar en las celebraciones de bautismo de los demás herederos de Felipe IV y sus esposas, tanto de Isabel de Borbón como de Mariana de Austria, ya que el estudio pormenorizado de estos casos nos permitirá comprender mejor la realidad del ceremonial de bautismo de este reinado. A partir de lo expresado a lo largo de estas líneas, resulta evidente la importancia que tuvo entre 1625 y 1626 la infanta María Eugenia, quien, a pesar de no ser una figura demasiado conocida para la historiografía, gozó de un papel protagonista en el reinado de Felipe IV durante sus veinte meses de vida.

\section{Referencias}

\section{Fuentes documentales}

Archivo General de Palacio (AGP). Madrid. Fondo: Sección Histórica.

Archivo de la Real Chancillería de Valladolid (ARCV). Valladolid. Fondo: Cédulas y Pragmáticas. Archivo Histórico Nacional (AHN). Madrid. Fondo: Códices.

Biblioteca Nacional de España(BNE). Madrid. Fondo: Manuscritos.

Biblioteca Central de la Universitat de Barcelona. Barcelona.

Biblioteca de la Universidad de Sevilla. Sevilla. Fondo: Fondo Antiguo.

Bibliothèque Municipale Besançon. Besançon. Fondo: Jules Chifflet, Colección Pièces historiques cérémoniales.

Real Academia de la Historia. Madrid. 


\section{Fuentes bibliográficas}

Albadalejo Martínez, María. "Fasto y etiqueta de la casa de Austria. Breves apuntes sobre su origen y evolución." Imafronte, no. 19-20 (2008): 9-19.

Alenda y Mira, Jenaro. Solemnidades y fiestas públicas de España. Madrid: Establecimiento Tipográfico "Sucesores de Rivadeneyra", Impresores de la Real Casa, 1903.

Bouza Álvarez, Fernando. "El rey, a escena. Mirada y lectura de la fiesta en la génesis del efímero moderno." Espacio, Tiempo y Forma, Serie IV, Historia Moderna, no. 10 (1997): 33-52.

Bravo Lozano, Jesús. "La Capilla Real de Felipe IV: ceremonial de exaltación en un espacio integrador." Libros de la Corte, no. 11 (otoño-invierno 2015): 28-50.

Checa, Fernando. Tesoros de la Corona de España. Tapices flamencos en el siglo de Oro. Madrid: Fons Mercator, 2010.

Chiva Beltrán, Juan. "Triunfos de la Casa de Austria: entradas reales en la Corte de Madrid." Potestas. Estudios del Mundo Clásico e Historia del Arte 4, no. 4 (2011): 211-228.

De Carlos Varona, María Cruz. Nacer en Palacio. El ritual del nacimiento en la corte de los Austrias. Madrid: Centro de Estudios Europa Hispánica, 2018.

Ferrari, Antonio. Aparato festivo en el bautismo de la serenisima Infanta D. María Eugenia, celebrada con espléndida pompa en la Real Capilla de Su Magestad a Siete de lunio de 1626. Madrid: Bernardino de Guzmán, 1626.

---. Aparato festivo en el bautismo de la serenisima Infanta D. María Eugenia, celebrada con espléndida pompa en la Real Capilla de Su Magestad a Siete de Iunio de 1626. Sevilla: Juan de Cabrera, 1626.

---. Aparato festivo en el bautismo de la serenisima Infanta D. María Eugenia, celebrada con espléndida pompa en la Real Capilla de Su Magestad a Siete de Iunio de 1626. Barcelona: en casa de Sebastián y Jaime Matevad, 1626.

Florez, Enrique. Memoria de las reinas católicas. T. 2. Madrid: Oficina de la Viuda de Marín, 1970.

García Bernal, José Jaime. El fasto público en la España de los Austrias. Sevilla: Secretariado de Publicaciones Universidad de Sevilla, 2006.

---. "De 'Felipe el Grande' al 'Rey Pacífico'. Discursos festivos y funerales durante el reinado de Felipe IV." Obradoiro de Historia Moderna, no. 20 (2017): 73-104.

Giordano, Silvano y Salvador Salort Pons. "La legación de Francesco Barberini en España: unos retratos para el cardenal y un breve pontificio para Velázquez, 'clericó coniugato'." Archivo Español de Arte, no. 77 (2004): 159-170.

González Palencia, Ángel. Noticias de Madrid, 1621-1627. Madrid: Ayuntamiento de Madrid, Publicaciones de la Sección de Cultura e información, 1942.

Hijano Pérez, Ángeles. "Protocolo y ritual en los bautizos de la Monarquía Española." Libros de la Corte, no. 6 (primavera-verano 2013): 8-26.

Martínez Millán, José y José Eloy Hortal Muñoz, dirs. La Corte de Felipe IV (1621-1665). Reconfiguración de la Monarquía católica. T. 2. Madrid: Ediciones Polifemo, 2015.

Noel, Charles C., "La etiqueta borgoñona en la corte de España." Manuscrits, no. 22 (2015): 139-160. 
Pascual Molina, Jesús F. "Los tapices de la empresa de Túnez." Arte, Poder y Sociedad en la Edad Moderna. Consultado el 26 de junio de 2020. https://arteysociedad. blogs.uva.es/multimedia/exposiciones-virtuales/el-viaje-de-las-obras-de-arte/ los-tapices-de-la-empresa-de-tunez/

Robles do Campo, Carlos. "Los infantes de España en los siglos XVI y XVII." Anales de la Real Academia Matritense de Heráldica y Genealogía, no. 9 (2005-2006): 383-414.

Rodríguez Moya, Inmaculada. "El bautismo regio en la corte hispánica: arte y ritual del siglo XVI al XVII." Archivo Español de Arte 91, no. 364 (octubre-diciembre 2018): 349-366.

Vázquez Gestal, Pablo. "La corte en la historiografía modernista española. Estado de la cuestión y bibliografía." Cuadernos de Historia Moderna. Anejos, no. 2 (2003): 269-310. 